\title{
Synthesis and antibacterial activity of novel titanium dioxide doped with silver
}

\author{
A. Kedziora $\cdot$ W. Strek $\cdot$ L. Kepinski . \\ G. Bugla-Ploskonska $\cdot$ W. Doroszkiewicz
}

Received: 15 September 2011 / Accepted: 12 January 2012/Published online: 31 January 2012

(C) The Author(s) 2012. This article is published with open access at Springerlink.com

\begin{abstract}
Pure and silver doped nanoparticles of titanium dioxide $\left(\mathrm{TiO}_{2}\right)$ was prepared using novel, modified sol-gel method. The samples were characterized by transmission electron microscopy, X-ray diffraction, $\mathrm{N}_{2}$ adsorption measurement, atomic absorption spectroscopy (AAS), UVvis spectroscopy (UV-vis). The antibacterial activity of the prepared samples was indicated by minimal inhibitory concentrations (MIC) and minimal bactericidal concentrations (MBC) values according to the reference methods of Clinical and Laboratory Standards Institute for the determination of MIC of aerobic bacteria by broth microdilution. The results showed very good antibacterial activity of silver nanoforms to bacteria strains: Gram-positive Staphylococcus aureus and Gram-negative Escherichia coli and Klebsiella pneumoniae. The sensitivity of the tested bacteria to silver nanoforms depends on the crystalline form of the carrier- $-\mathrm{TiO}_{2}$, its surface area, porosity, the content of silver, its particle size and oxidation state. The originality of this work is the synthesis of novel type of nanocomposites $\mathrm{TiO}_{2}$ doped with silver and determination its excellent antibacterial activity.
\end{abstract}

Keywords Titanium dioxide $\cdot$ Silver $\cdot$ Nanoparticles · Bacteria

\footnotetext{
A. Kedziora $(\bowtie) \cdot$ G. Bugla-Ploskonska · W. Doroszkiewicz Department of Microbiology, University of Wroclaw, Institute of Genetics and Microbiology,

Przybyszewskiego 63/77, 51-148 Wrocław, Poland

e-mail: anna.kedziora@microb.uni.wroc.pl

W. Strek · L. Kepinski

Institute of Low Temperature and Structure Research, Polish

Academy of Sciences, Okolna 2, 50-422 Wroclaw, Poland
}

\section{Introduction}

With regards to its unique photocatalytic activity, titanium dioxide $\left(\mathrm{TiO}_{2}\right)$ has received considerable attention in recent years. Since 1977, following Frank and Bard [1] confirming the possibility of using $\mathrm{TiO}_{2}$ in the degradation of cyanide in water; there has been an increased interest in the environmental, medical and biological application of $\mathrm{TiO}_{2}[1,2]$. Additional research has confirmed its good efficacy in the degradation of a wide variety of organic and inorganic pollutants [3-10]. Photocatalytic oxidation as a technique for microbial disinfection was first demonstrated by Matsanuga et al. [9]. Titanium white is, among other things, used in cosmetics as a white pigment in cream, face powder, lipstick and sunscreen [11]. $\mathrm{TiO}_{2}$ is found in three main crystallographic forms in the environment: anatase, rutile and brookite [12]. The anatase type has been acknowledged as the highest in photocatalytic properties and may be used in various applications, also as a carrier of biologically active particles e.g. silver [13]. There is not much information about biological activity of anatase without UV irradiation which is necessary for photocalatytic activity. There is also no information about biological activity of amorphous $\mathrm{TiO}_{2}$ as a carrier of silver ions or silver nanoparticles. We prepared various forms of $\mathrm{TiO}_{2}$-amorphous and anatase (both doped with silver) and compared its antibacterial activity without UV irradiation.

Silver has been exploited for its medicinal properties for centuries. Its biological activity has been confirmed against Gram-positive and Gram-negative, aerobe and anaerobe bacteria, fungi and protozoan. Chemotherapeutic agents as opposed to antibiotic ones have shown an oligodynamic effect [14-18]. Involving metals by bacteria from culture medium can take place by physical adsorption of ions to 
the surface of bacteria (van der Waals force) exchanging ions or connections between metal ion and groups of macro and macromolecules, especially in elements such as oxygen, sulfur and nitrogen [19]. Silver is toxic to microorganisms and poisons the respiratory enzymes and components in the microbial electron transport system. Additionally, silver can interact with structural proteins such as fimbriae-protein structures located on the cell's surface of bacteria, responsible for adhesion to the artificial surface or macroorganism cells. Other research connects silver accumulation in bacterial cells and its interaction with cytosolic proteins, mitochondrial enzymes and DNA or RNA synthesis [20]. Resistance of microorganisms to silver is rare $[20,21]$. Bacteria can combat metal ions by decreasing the synthesis of outer membrane proteins, cellular efflux system (active or chemoosmotic) [21] and bound by cells in the form of an intracellular complex [20]. Bacteria can also transform ions to their less toxic form [21, 22]. It confirms very good properties of silver in biological and medical applications as alternative way of killing bacteria.

The originality of this work is the new method of synthesis of very small particles of $\mathrm{TiO}_{2}$ doped with silver as a new type of nanocomposities, which exhibit excellent antimicrobial efficacy without additional factor such as UV irradiation. The tested bacteria strains (Gram-positive Staphylococcus aureus and Gram-negative Escherichia coli and Klebsiella pneumoniae) are responsible for most hospital infections such as: wound infections and urinary track infections. We showed that the titanium dioxide doped silver nanocomposites can be used in numerous biomedical, pharmaceutical and industrial applications also without UV irradiations.

\section{Experimental}

\subsection{Reagents}

Titanium (IV) n-butoxide ( $\mathrm{Ti}(\mathrm{O}-\mathrm{Bu}), 99 \%)$, ethyl alcohol $\left(\mathrm{C}_{2} \mathrm{H}_{5} \mathrm{OH}, 96 \%\right)$, methyl alcohol $\left(\mathrm{CH}_{3} \mathrm{OH}\right)$, ammonium hydroxide $\left(\mathrm{NH}_{3} \times \mathrm{H}_{2} \mathrm{O}, 25 \%\right)$, hydrofluoric acid (HF, $40 \%$ ) and acetone were purchased from POCh. Glucose $\left(\mathrm{C}_{6} \mathrm{H}_{12} \mathrm{O}_{6}\right)$, potassium hydroxide $(\mathrm{KOH})$ was bought from Chempur, and the silver nitrate $\left(\mathrm{AgNO}_{3}, 99 \%\right)$ was purchased from Aldrich. Deionized water was used in each of the experimental preparations.

\subsection{Medium}

Muller Hinton Agar (MHA), Muller Hinton Broth (MHB) was purchased from Biocorp.
2.3 Synthesis of amorphous and crystalline $\mathrm{TiO}_{2}$ doped with silver $\left(\mathrm{TiO}_{2}: \mathrm{Ag}^{0}, \mathrm{TiO}_{2 \mathrm{a}}: \mathrm{Ag}^{0}, \mathrm{TiO}_{2}: \mathrm{Ag}^{0} / \mathrm{Ag}^{+}\right.$, $\mathrm{TiO}_{2 \mathrm{a}}: \mathrm{Ag}^{0} / \mathrm{Ag}^{+}, \mathrm{TiO}_{2}: \mathrm{Ag}^{0} / \mathrm{Ag}^{0}$ and $\mathrm{TiO}_{2 \mathrm{a}}: \mathrm{Ag}^{0} / \mathrm{Ag}^{0}$ nanocomposites)

Method synthesis of $\mathrm{TiO}_{2}$ doped with silver $\left(\mathrm{TiO}_{2}: \mathrm{Ag}^{0}\right.$ and $\mathrm{TiO}_{2 \mathrm{a}}: \mathrm{Ag}^{0}$ ) consists in doping $\mathrm{TiO}_{2}$ with silver during synthesis process.

Titanium dioxide doped with silver-amorphous $\mathrm{TiO}_{2}: \mathrm{Ag}^{0}$ and crystalline $\mathrm{TiO}_{2 \mathrm{a}}: \mathrm{Ag}^{0}$-were synthesized through modified sol-gel methods [23]. In our propose silver nanoparticles were incorporated in $\mathrm{TiO}_{2}$ matrix during the carrier synthesis. In the sol-gel process $\mathrm{TiO}_{2}$ is usually prepared by the following steps: hydrolysis and polycondensation of titanium alkoxides (Ti(OR)n). Sol-gel reaction occurred in acetone environment, in presence of catalyst (ammonium hydroxide) and hydrofluoric acid. Titanium n-butoxide $(6 \mathrm{ml})$ and hydrofluoric acid $(250 \mu \mathrm{l})$ was added drop wise to acetone $(50 \mathrm{ml})$ with stirring. Next, ammonium hydroxide $(2 \mathrm{ml})$ and diamminesilver $(\mathrm{I})\left(\left[\mathrm{Ag}(\mathrm{NH})_{2}\right]^{+}\right)$was added. The solution was stirred for $30 \mathrm{~min}$. Preparation of diamminesilver (I) $\left[\mathrm{Ag}\left(\mathrm{NH}_{3}\right)_{2}\right]^{+}$is described below.

The gel was then washed in methyl alcohol and water and centrifuged at $4,000 \mathrm{rpm}$. Ready gel was dried at $80^{\circ} \mathrm{C}$. In preparing the crystalline form it was calcined at $400^{\circ} \mathrm{C}$ for $10 \mathrm{~h}$ at a ramp rate $5^{\circ} \mathrm{C} / \mathrm{min}$ after drying.

Such prepared samples may be subjected to additional silvered. To prepare $\mathrm{TiO}_{2}$ doped with additional silver $\left(\mathrm{TiO}_{2}: \mathrm{Ag}^{0} / \mathrm{Ag}^{+}, \quad \mathrm{TiO}_{2}: \mathrm{Ag}^{0} / \mathrm{Ag}^{0}, \quad \mathrm{TiO}_{2 \mathrm{a}}: \mathrm{Ag}^{0} / \mathrm{Ag}^{+}\right.$and $\left.\mathrm{TiO}_{2 \mathrm{a}}: \mathrm{Ag}^{0} / \mathrm{Ag}^{0}\right)$ the powder of amorphous and crystalline $\mathrm{TiO}_{2}$ with silver $\left(\mathrm{TiO}_{2}: \mathrm{Ag}^{0}, \mathrm{TiO}_{2 \mathrm{a}}: \mathrm{Ag}^{0}\right)$ were treated with diamminesilver (I) $\left[\mathrm{Ag}\left(\mathrm{NH}_{3}\right)_{2}\right]^{+}$or diamminesilver (I) $\left[\mathrm{Ag}\left(\mathrm{NH}_{3}\right)_{2}\right]^{+}$and reducing factor (glucose). The process consisted of two steps: impregnation and/or reduction. First, the powder of $\mathrm{TiO}_{2}: \mathrm{Ag}^{0}$ and $\mathrm{TiO}_{2 \mathrm{a}}: \mathrm{Ag}^{0}-0.2 \mathrm{~g}$-was impregnated with a silver solution $\left[\mathrm{Ag}\left(\mathrm{NH}_{3}\right)_{2}\right]^{+}$at $22^{\circ} \mathrm{C}$ per $24 \mathrm{~h}(0.4 \mathrm{M})$ and distilled water (to final volume $22 \mathrm{ml}$ ). The products $\left(\mathrm{TiO}_{2}: \mathrm{Ag}^{0} / \mathrm{Ag}^{+}\right.$or $\left.\mathrm{TiO}_{2 \mathrm{a}}: \mathrm{Ag}^{0} / \mathrm{Ag}^{+}\right)$was then washed with methyl alcohol and water to remove the excess of silver and centrifuged at 4,000 rpm. Next samples with additional silver ions were abandon or were submitted to a reducing chemical factor-glucose $(6.8 \%)$ to prepared silvered $\mathrm{TiO}_{2}$ with double silver nanoparticles- $\mathrm{TiO}_{2}: \mathrm{Ag}^{0} /$ $\mathrm{Ag}^{0}$ or $\mathrm{TiO}_{2 \mathrm{a}}: \mathrm{Ag}^{0} / \mathrm{Ag}^{0}[24,25]$. The entire mixture was stirred for $15 \mathrm{~min}$ and stored at $70^{\circ} \mathrm{C}$ per $24 \mathrm{~h}$. The product was then washed with methyl alcohol and distilled water, centrifuged at 4,000 rpm and suspended in a suitable amount of water. All prepared samples are described in Table 1.

\subsection{Preparation of diamminesilver (I) $\left[\mathrm{Ag}\left(\mathrm{NH}_{3}\right)_{2}\right]^{+}$}

The diamminesilver (I) nitrate solution (Tollen's reagent) was prepared by taking $0.1 \mathrm{M}$ of the silver nitrate solution 
Table 1 Characteristics of prepared samples

\begin{tabular}{llllc}
\hline Sample & Kind of carrier & $\begin{array}{l}\text { Size of } \\
\text { carrier }(\mathrm{nm})\end{array}$ & $\begin{array}{l}\text { Size of silver } \\
\text { nanoparticles (nm) }\end{array}$ & $\begin{array}{l}\text { Contents of } \\
\text { silver (\%) }\end{array}$ \\
\hline $\mathrm{TiO}_{2}: \mathrm{Ag}^{0}$ & Amorphous $\mathrm{TiO}_{2}$ & $\leq 100 \mathrm{~nm}$ & $\leq 5 \mathrm{~nm}$ & 1.8 \\
$\mathrm{TiO}_{2}: \mathrm{Ag}^{0} / \mathrm{Ag}^{0}$ & Amorphous $\mathrm{TiO}_{2}$ & $\leq 100 \mathrm{~nm}$ & $\leq 5 \mathrm{~nm}$ & 11.6 \\
$\mathrm{TiO}_{2}: \mathrm{Ag}^{0} / \mathrm{Ag}^{+}$ & Amorphous $\mathrm{TiO}_{2}$ & $\leq 100 \mathrm{~nm}$ & $\mathrm{n} / \mathrm{a}$ & 11.6 \\
$\mathrm{TiO}_{2 \mathrm{a}}: \mathrm{Ag}^{0}$ & Crystalline $\mathrm{TiO}_{2}$, anatase & $\leq 50$ & $\leq 5 \mathrm{~nm}$ & 1.6 \\
$\mathrm{TiO}_{2 \mathrm{a}}: \mathrm{Ag}^{0} / \mathrm{Ag}^{0}$ & Crystalline $\mathrm{TiO}_{2}$, anatase & $\leq 50$ & $\leq 5 \mathrm{~nm}$ & 2.2 \\
$\mathrm{TiO}_{2 \mathrm{a}}: \mathrm{Ag}^{0} / \mathrm{Ag}^{+}$ & Crystalline $\mathrm{TiO}_{2}$, anatase & $\leq 50$ & $\mathrm{n} / \mathrm{a}$ & 2.2 \\
\hline
\end{tabular}

and adding a solution of potassium hydroxide to form a brown precipitate $[24,25]$. The sediment was then dissolved in ammonium hydroxide (25\%), and stirred until all the precipitate disappeared.

\subsection{Characteristics of $\mathrm{TiO}_{2}: \mathrm{Ag}^{0}$}

The morphology of the samples was investigated by transmission electron microscopy (TEM, Philips CM20 Super Twin). The crystalline phase was identified using a X-ray diffraction (XRD, Stoe). Porosity and BrunauerEmmett-Teller BET surface area were obtained from nitrogen adsorptions isotherms (Autosorb 1-C, Quantachrome Instruments). The contents of silver were measured using an atomic absorption spectroscopy (AAS-Perkin Elmer 1100).

\subsection{Bacteria strains}

The following bacteria strains from the American Type Culture Collection were tested:

Staphylococcus aureus ATCC 6538 (Gram-positive bacteria), E. coli ATCC 11229 (Gram-negative bacteria), K. pneumoniae ATCC 4352 (Gram-negative bacteria). Clinical isolates of bacteria (from urinary track infections and wounds) strains were also tested (from species of $S$. aureus, E. coli and K. pneumoniae).

Before the test the purity of the colonies were verified. For the antibacterial test 16-20 h of bacteria incubation in MHB was used.

2.7 Antibacterial effect of amorphous and crystalline titanium doped with silver $\left(\mathrm{TiO}_{2}: \mathrm{Ag}^{0}, \mathrm{TiO}_{2 \mathrm{a}}: \mathrm{Ag}^{0}\right.$, $\mathrm{TiO}_{2}: \mathrm{Ag}^{0} / \mathrm{Ag}^{+}, \mathrm{TiO}_{2 \mathrm{a}}: \mathrm{Ag}^{0} / \mathrm{Ag}^{+}, \mathrm{TiO}_{2}: \mathrm{Ag}^{0} / \mathrm{Ag}^{0}$ and $\mathrm{TiO}_{2 \mathrm{a}}: \mathrm{Ag}^{0} / \mathrm{Ag}^{0}$ nanospheres)

The antibacterial effect of amorphous and crystalline $\mathrm{TiO}_{2}: \mathrm{Ag}^{0}, \mathrm{TiO}_{2 \mathrm{a}}: \mathrm{Ag}^{0}, \mathrm{TiO}_{2}: \mathrm{Ag}^{0} / \mathrm{Ag}^{+}, \mathrm{TiO}_{2 \mathrm{a}}: \mathrm{Ag}^{0} / \mathrm{Ag}^{+}$, $\mathrm{TiO}_{2}: \mathrm{Ag}^{0} / \mathrm{Ag}^{0}$ and $\mathrm{TiO}_{2 \mathrm{a}}: \mathrm{Ag}^{0} / \mathrm{Ag}^{0}$ nanospheres was determined by minimal inhibitory concentration (MIC) and minimal bactericidal concentration (MBC) values according to reference methods of Clinical and Laboratory
Standards Institute (CLSI) for the determination of MICs of aerobic bacteria by broth microdilution. The MIC values were the lowest concentration of silver on a microplate that inhibited the growth of bacteria after 16-19 h of incubation at $37^{\circ} \mathrm{C}$. MBC had the lowest concentration of the extract in which $99.9 \%$ of bacteria were killed [26, 27]. The lower MIC and MBC values the better antibacterial activity. In the experimental procedure, MHB and MHA were used as a medium. Stock of the antimicrobial agent's dilution was prepared according to the reference method and $200 \mathrm{ml}$ per every spot were poured. Preparation of inoculum: adjusting the 0.5 McFarland standard contains approximately $1-2 \times 10^{8} \mathrm{CFU} / \mathrm{ml}$ (1) and diluted 0.5 McFarland suspension in sterile saline in the ratio of 1:10 (2). The final inoculum was $10^{4} \mathrm{CFU}$ per spot. Nanoparticles-free spots with medium and cultures were used as growth controls.

\section{Results and discussion}

\subsection{Synthesis and characterization of silvered $\mathrm{TiO}_{2}$}

We have found that $\mathrm{Ti}(\mathrm{O}-\mathrm{Bu})$ hydrolysis and sol-gel condensation in the presence of acetone is much better than in ethanol (data not described) and dropping small concentrations of hydrofluoric acid causes a decrease in the size of $\mathrm{TiO}_{2}$ particles. The particle size of $\mathrm{TiO}_{2}$ depends on composition, calcination temperature and the grain size [28]. Although the radius of silver ion $\left(\mathrm{Ag}^{+}\right)$is much larger than that of $\mathrm{Ti}^{4+}$ ion and $\mathrm{Ag}^{+}$ion introduced by the impregnation process couldn't enter into the lattice of the anatase phase to form a stable solid solution [29], adding diamminesilver (I) to the prepared mixture of $\mathrm{TiO}_{2}$ produced silver nanoparticles of size less than $5 \mathrm{~nm}$ embedded in the structure and on the surface of $\mathrm{TiO}_{2}$. Silver embodied to the $\mathrm{TiO}_{2}$ structure during synthesis $\left(\mathrm{TiO}_{2}: \mathrm{Ag}^{0}\right.$ and $\mathrm{TiO}_{2 \mathrm{a}}: \mathrm{Ag}^{0}$ ) can also be a source for additional content of silver. It caused increase content of silver from 1.8 to $11.6 \%$ (for amorphous $\mathrm{TiO}_{2}: \mathrm{Ag}^{0}$ ) and from 1.6 to $2.2 \%$ (for crystalline $\mathrm{TiO}_{2 \mathrm{a}}: \mathrm{Ag}^{0}$ ). We indicated experimentally that the synthesis time can be reduced from 120 to $30 \mathrm{~min}$, which does not impact the efficacy of technology. 


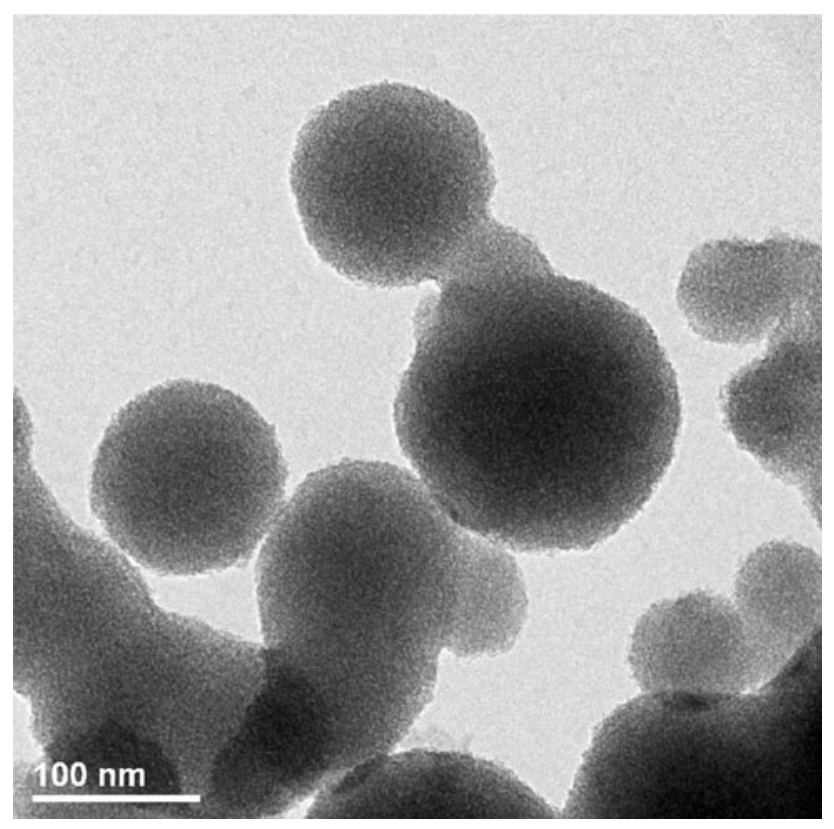

Fig. 1 TEM image of an amorphous $\mathrm{TiO}_{2}: \mathrm{Ag}^{0}$

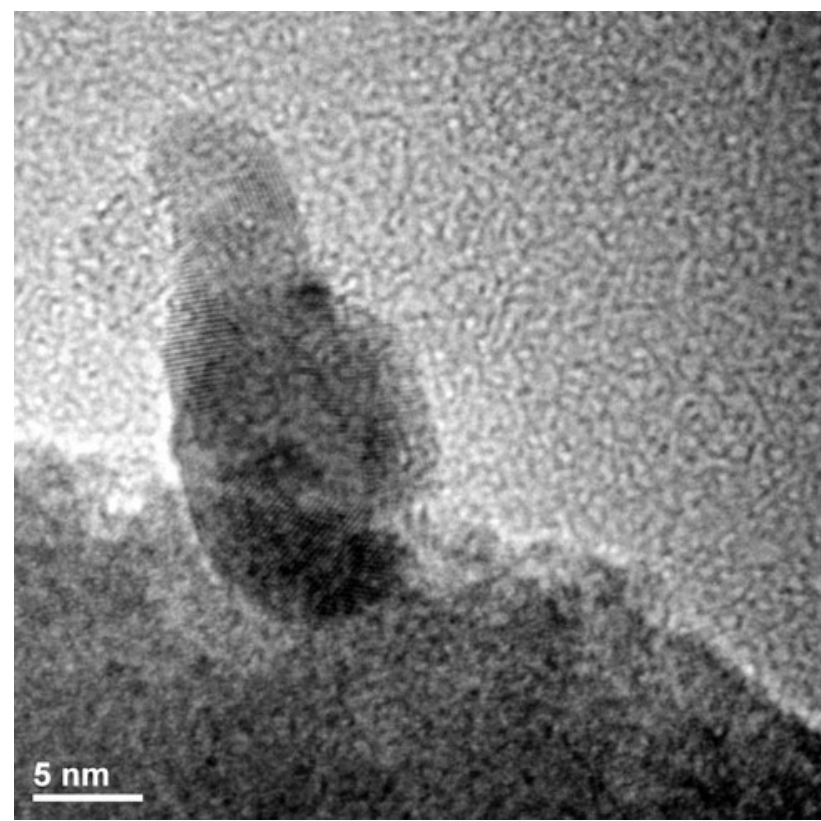

Fig. 2 TEM image of silver nanoparticles located at the surface of the amorphous $\mathrm{TiO}_{2}\left(\mathrm{TiO}_{2}: \mathrm{Ag}^{0}\right)$

Figures 1-3 show TEM images of the prepared basic samples. Figure 1 shows amorphous $\mathrm{TiO}_{2}: \mathrm{Ag}^{0}$ and silver nanoparticles on the amorphous $\mathrm{TiO}_{2}$ are presented on Fig. 2. We have indicated that $\mathrm{TiO}_{2}$ size is smaller than $100 \mathrm{~nm}$ and particle size of silver embodied to the structure of $\mathrm{TiO}_{2}$ is smaller than $5 \mathrm{~nm}$. Figure 3 shows crystalline $\mathrm{TiO}_{2}$ doped with silver during the synthesis $\left(\mathrm{TiO}_{2 \mathrm{a}}: \mathrm{Ag}^{0}\right)$. There are seen particles of anatase (with size about $50 \mathrm{~nm}$ )

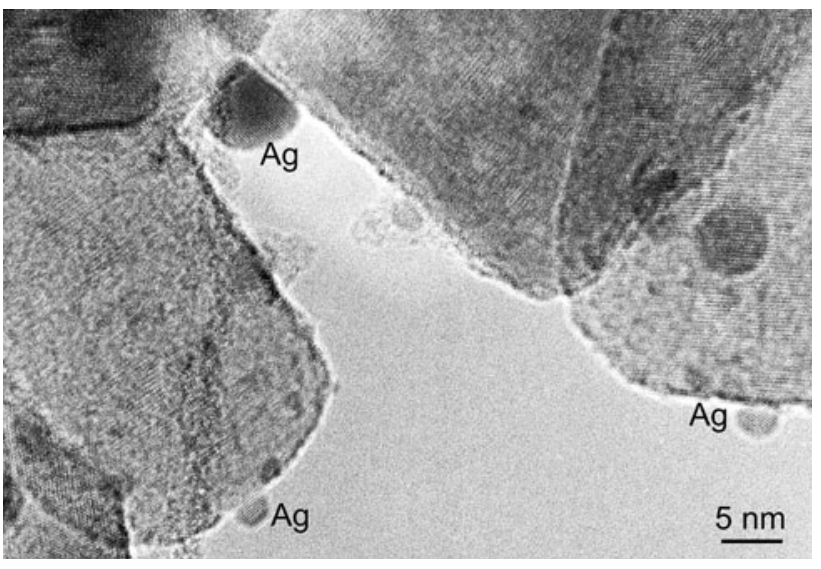

Fig. 3 TEM image of crystalline $\mathrm{TiO}_{2 \mathrm{a}}: \mathrm{Ag}^{0}$

Table 2 BET surface area and pore size of amorphous $\mathrm{TiO}_{2}: \mathrm{Ag}^{0}$ and crystalline $\mathrm{TiO}_{2 \mathrm{a}}: \mathrm{Ag}^{0}$

\begin{tabular}{lcl}
\hline Sample & $\mathrm{S}_{\mathrm{BET}}\left(\mathrm{m}^{2} / \mathrm{g}\right)$ & Pore size $(\mathrm{nm})$ \\
\hline $\mathrm{TiO}_{2}: \mathrm{Ag}^{0}$ & $464 \pm 5$ & 3 \\
$\mathrm{TiO}_{2 \mathrm{a}}: \mathrm{Ag}^{0}$ & $37.5 \pm 0.2$ & 8 \\
\hline
\end{tabular}

and silver nanoparticles with size below $5 \mathrm{~nm}$. Calcination of the amorphous $\mathrm{TiO}_{2}: \mathrm{Ag}^{0}$ caused an increase of $\mathrm{TiO}_{2}$ particles size and didn't change the silver crystallite size. In result the specific surface area of the powder decreased from $424 \pm 8 \mathrm{~m}^{2} / \mathrm{g}$ (for amorphous $\mathrm{TiO}_{2}: \mathrm{Ag}^{0}$ ) to $37.5 \pm 0.2 \mathrm{~m}^{2} / \mathrm{g}$ (for crystalline $\mathrm{TiO}_{2 \mathrm{a}}: \mathrm{Ag}^{0}$ ) (data shown in Table 2).

The crystalline character of $\mathrm{TiO}_{2}$ was checked by electron diffraction. The electron diffraction pattern in Fig. 4 shows that the samples are composed of an amorphous or a crystalline form. In the case of the amorphous sample $\mathrm{TiO}_{2}: \mathrm{Ag}^{0}$ diffuse rings in diffraction pattern are visible (Fig. 4a). The diffraction pattern of the crystalline sample $\mathrm{TiO}_{2 \mathrm{a}}: \mathrm{Ag}^{0}$ confirms its anatase form (Fig. 4b). Results obtained by electron diffraction coincide with the XRD results. XRD of the amorphous and crystalline $\mathrm{TiO}_{2}$ doped with silver $\left(\mathrm{TiO}_{2}: \mathrm{Ag}^{0}\right.$ and $\left.\mathrm{TiO}_{2 \mathrm{a}}: \mathrm{Ag}^{0}\right)$ are shown on the Fig. 5. All reflections in the diffraction patterns of $\mathrm{TiO}_{2}$ shown in Fig. 5b were identified as belonging to anatase. In the pattern of the amorphous $\mathrm{TiO}_{2}$, no reflections are observed (Fig. 5a). However, similar as in [30], there are no obvious peaks showing the presence of silver in the XRD of the silver doped titania samples (Fig. 5a, b). It probably results from very small size of silver nanoparticles $(<5 \mathrm{~nm})$ and its low content (below 2\%). In comparison to Chao et al. [29] $\mathrm{TiO}_{2 \mathrm{a}}: \mathrm{Ag}^{0}$ powder calcined already at $400^{\circ} \mathrm{C}$ is well crystallized.

The room temperature UV-vis diffuse reflectance spectra of amorphous and crystalline samples doped with 


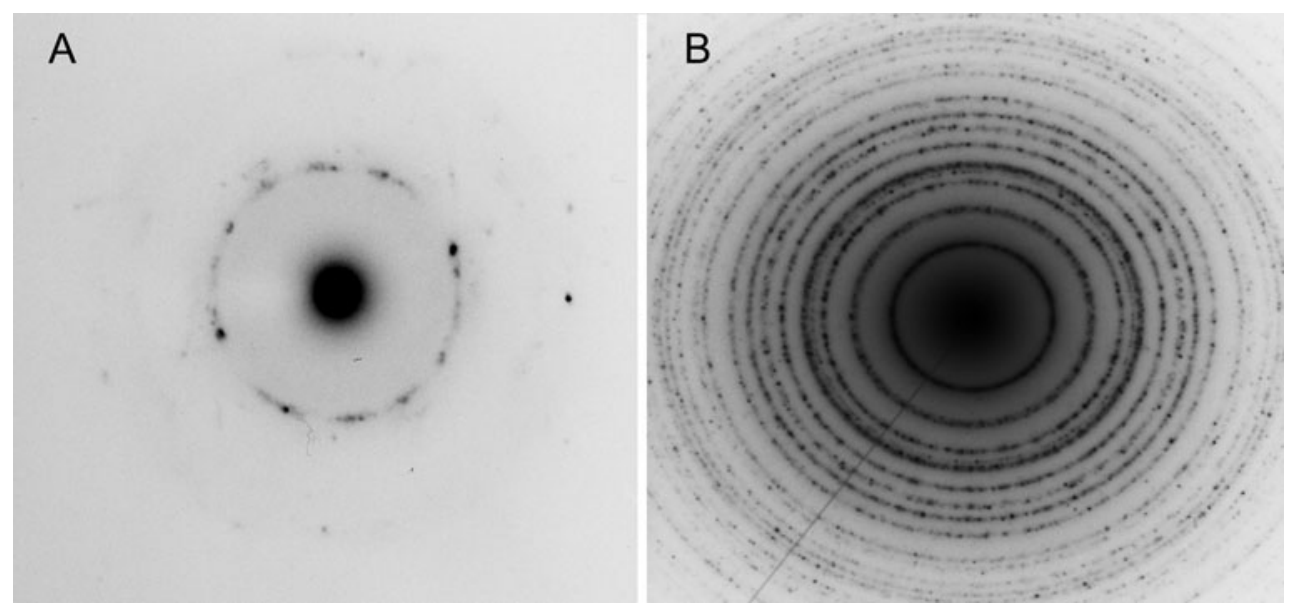

Fig. 4 Electron diffraction patterns of: (a) amorphous $\mathrm{TiO}_{2}: \mathrm{Ag}^{0}$ and (b) crystalline $\mathrm{TiO}_{2 \mathrm{a}}: \mathrm{Ag}^{0}$

Fig. 5 XRD patterns of: (a) amorphous $\mathrm{TiO}_{2}: \mathrm{Ag}^{0}$ powder and (b) crystalline $\mathrm{TiO}_{-2 \mathrm{a}}: \mathrm{Ag}^{0}$ powder
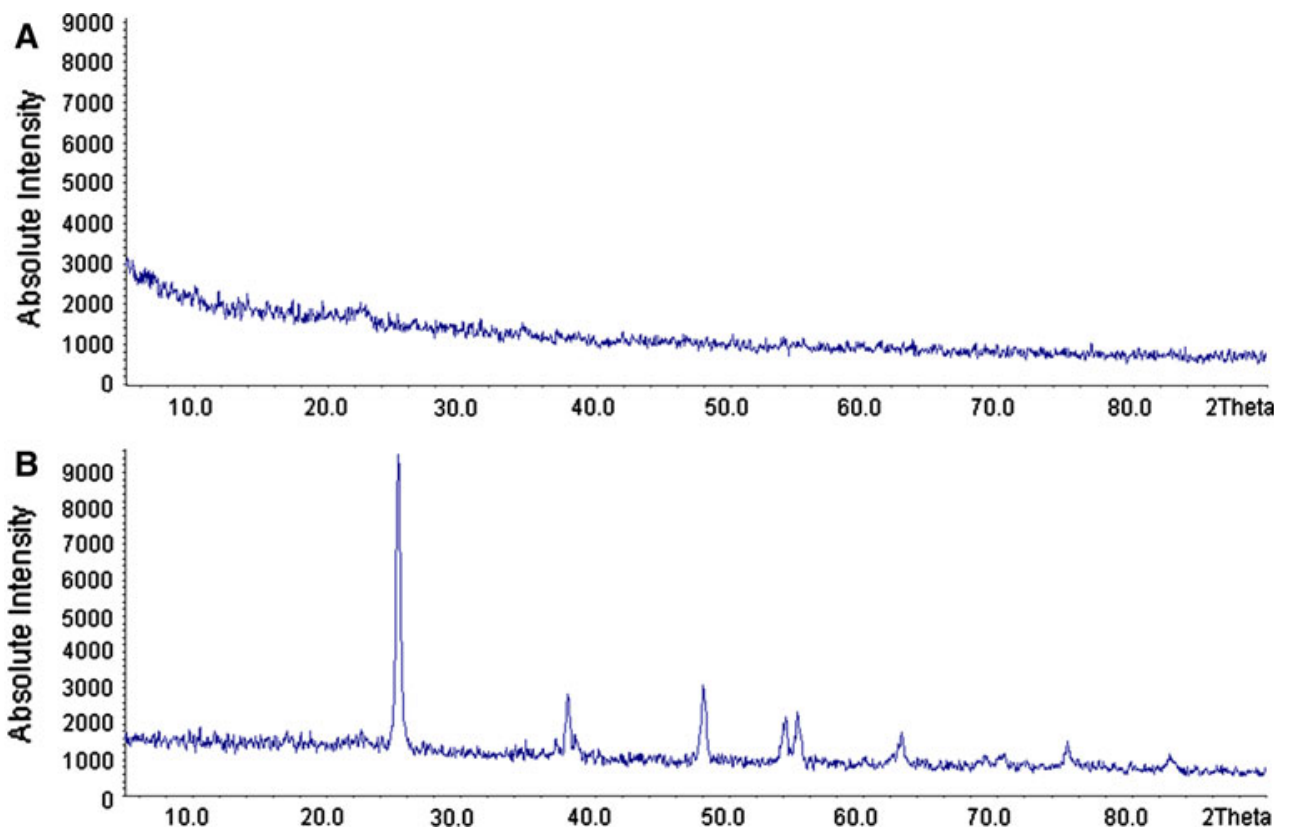

silver are presented in Fig. 6. It is well known that the UVvis absorption spectra of the Ag nanoparticles with a size range from 3 to $20 \mathrm{~nm}$ exhibit a single absorption peak at $410 \mathrm{~nm}$ [6]. As can be seen from curve A in Fig. 6 nanocomposites of crystalline $\mathrm{TiO}_{2}$ have a broad intense absorption below ca. $400 \mathrm{~nm}$. This is the characteristic absorption of $\mathrm{TiO}_{2}$ corresponding to the charge transfer process form the valence band to conduction band in anatase [31]. Lack of visible silver absorption peak in samples $\mathrm{TiO}_{2}: \mathrm{Ag}^{0}$ (B) and $\mathrm{TiO}_{2 \mathrm{a}}: \mathrm{Ag}^{0}$ (A) can be due to small size or low concentration of the silver nanoparticles in the $\mathrm{TiO}_{2}$ powder (Fig. 6).

Figure 7 illustrates the $\mathrm{N}_{2}$ adsorption-desorption isotherm of the powders. The isotherm of $\mathrm{TiO}_{2}: \mathrm{Ag}^{0}$ powder before annealing is a typical type IV with hysteresis and isotherm of $\mathrm{TiO}_{2 \mathrm{a}}$ : $\mathrm{Ag}^{0}$ powder is typical for mesoporous adsorbent (pore diameter from 2 to $50 \mathrm{~nm}$ ). Effect of the drying and calcination temperature on the surface area and pore size of the both prepared samples are summarized in Table 2. The surface area of the powders decreased drastically while their pore size increased after calcination at $400^{\circ} \mathrm{C}[32]$.

\subsection{Antibacterial activity}

The originality of this work is the synthesis of novel type of $\mathrm{TiO}_{2}$ and determination antibacterial activity its crystalline and non crystalline forms. Results of the MIC and MBC values obtained for all samples are summarized in Tables 3, 4. We tested antimicrobial activity of basic forms- $\mathrm{TiO}_{2}$ doped with silver $\left(\mathrm{TiO}_{2}: \mathrm{Ag}^{0}\right.$ and $\left.\mathrm{TiO}_{2 \mathrm{a}}: \mathrm{Ag}^{0}\right)$ and samples with additional silver count $\left(\mathrm{TiO}_{2}: \mathrm{Ag}^{0} / \mathrm{Ag}^{+}\right.$, 


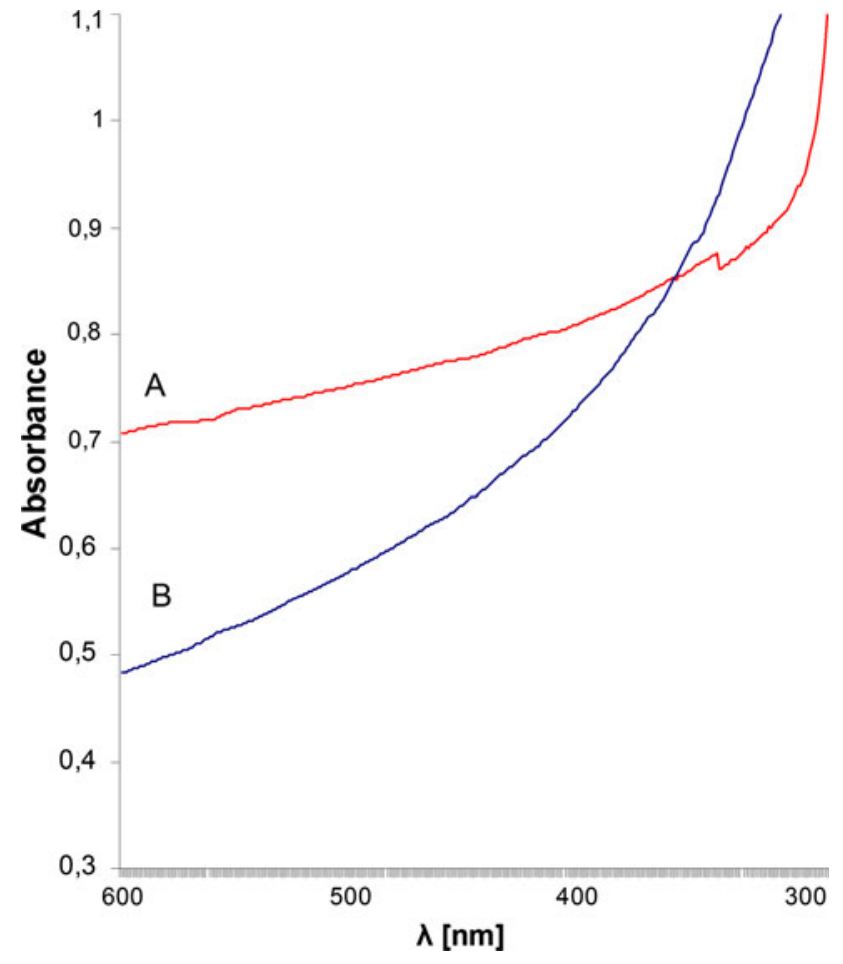

Fig. 6 UV-vis spectra of: (a) crystalline $\mathrm{TiO}_{2 \mathrm{a}}: \mathrm{Ag}^{0}$ and (b) amorphous $\mathrm{TiO}_{2}: \mathrm{Ag}^{0}$

$\mathrm{TiO}_{2}: \mathrm{Ag}^{0} / \mathrm{Ag}^{0}, \mathrm{TiO}_{2 \mathrm{a}}: \mathrm{Ag}^{0} / \mathrm{Ag}^{+}$and $\left.\mathrm{TiO}_{2 \mathrm{a}}: \mathrm{Ag}^{0} / \mathrm{Ag}^{0}\right)$. All samples were tested against Gram-positive and Gramnegative bacteria. The best efficacy indicate basic sample based on anatase $\mathrm{TiO}_{2 \mathrm{a}}: \mathrm{Ag}^{0}$. MIC value of this powder is very low for all bacteria strains: $0.4 \mu \mathrm{g} / \mathrm{ml}$ ! However
Keleher et. al. [33] in their research obtained MIC values for the crystalline $\mathrm{TiO}_{2} / \mathrm{Ag}^{0}$ particles at the level of $6.4 \mu \mathrm{g} /$ $\mathrm{ml}$ for $E$. coli and $3.9 \mu \mathrm{g} / \mathrm{ml}$ for $S$. aureus strains. Very good efficacy also indicates a sample with additional silver nanoparticles form $\left(\mathrm{Ag}^{0}\right)$ of the same samples $\left(\mathrm{TiO}_{2 \mathrm{a}}: \mathrm{Ag}^{0}\right.$ / $\mathrm{Ag}^{0}$ ): MIC values from 0.4 to $3.2 \mu \mathrm{g} / \mathrm{ml}$ (depending on bacteria strains). It is interesting that antibacterial activity is inversely proportional to surface area (lower in crystalline forms). Results confirm that affecting factor is also silver count and size; the lower count of silver particles, the better antibacterial efficacy (Tables 3, 4). It is also interesting that antibacterial activity dependence on silver oxidation state. In case of amorphous and crystalline $\mathrm{TiO}_{2}$ is better for sample with additional silver ions $\left(\mathrm{TiO}_{2}: \mathrm{Ag}^{0} /\right.$ $\mathrm{Ag}^{+}$and $\mathrm{TiO}_{2 \mathrm{a}}: \mathrm{Ag}^{0} / \mathrm{Ag}^{+}$) than additional silver nanoparticles $\left(\mathrm{TiO}_{2}: \mathrm{Ag}^{0} / \mathrm{Ag}^{0}\right.$ and $\left.\mathrm{TiO}_{2 \mathrm{a}}: \mathrm{Ag}^{\mathrm{O}} / \mathrm{Ag}^{\mathrm{O}}\right)$. This may be related to the ionization efficacy of $\mathrm{Ag}^{+}$on the surface of the particles and its ability to be released from the particles and diffuse to the bacterial cell wall. In case of amorphous and crystalline form of $\mathrm{TiO}_{2}$ doped with additional silver ions count (samples signed as $\mathrm{TiO}_{2}: \mathrm{Ag}^{0} / \mathrm{Ag}^{+}$and $\mathrm{TiO}_{2 \mathrm{a}}: \mathrm{Ag}^{0} / \mathrm{Ag}^{+}$) we have indicated MIC values approach to $\mathrm{MBC}$ values. It prove high antibacterial efficacy We suggest that samples, which already has silver present in the form of $\mathrm{Ag}^{+}$, can directly react with cell membranes, whereas the $\mathrm{Ag}$ metal bound to the $\mathrm{TiO}_{2}$ particles surface must first dissolution to form $\mathrm{Ag}^{+}$and then migrate to the bacteria cell. Keleher et al. [33] suggested that the smaller amounts of silver ions are needed to produce the same antibacterial effect as Ag metal.
Fig. 7 BET adsorptiondesorption of amorphous $\mathrm{TiO}_{2}: \mathrm{Ag}^{0}$ and crystalline $\mathrm{TiO}_{2 \mathrm{a}}: \mathrm{Ag}^{0}$

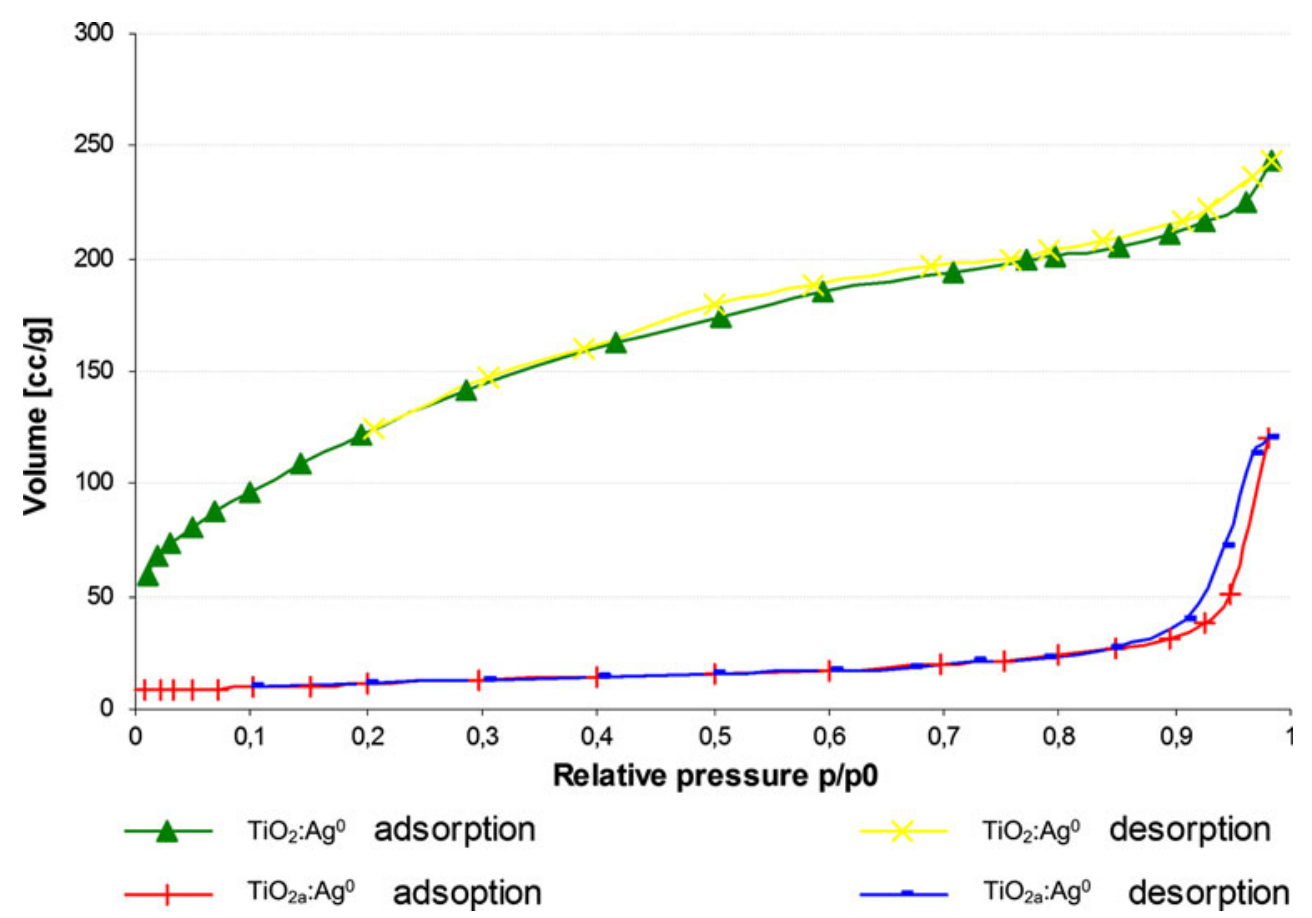


Table 3 MIC and MBC values of amorphous $\mathrm{TiO}_{2}: \mathrm{Ag}, \mathrm{TiO}_{2}: \mathrm{Ag}^{0} / \mathrm{Ag}^{+}$and $\mathrm{TiO}_{2}: \mathrm{Ag}^{0} / \mathrm{Ag}^{0}$ of references and clinical bacteria strains

\begin{tabular}{|c|c|c|c|c|c|c|}
\hline Bacteria strains & $\begin{array}{l}\mathrm{MIC}(\mu \mathrm{g} / \mathrm{ml}) \\
\mathrm{TiO}_{2}: \mathrm{Ag}^{0}\end{array}$ & $\operatorname{MBC}(\mu \mathrm{g} / \mathrm{ml})$ & $\begin{array}{l}\mathrm{MIC}(\mu \mathrm{g} / \mathrm{ml}) \\
\mathrm{TiO}_{2}: \mathrm{Ag}^{0} / \mathrm{Ag}^{+}\end{array}$ & MBC $(\mu \mathrm{g} / \mathrm{ml})$ & $\begin{array}{l}\mathrm{MIC}(\mu \mathrm{g} / \mathrm{ml}) \\
\mathrm{TiO}_{2}: \mathrm{Ag}^{0} / \mathrm{Ag}^{0}\end{array}$ & $\mathrm{MBC}(\mu \mathrm{g} / \mathrm{ml})$ \\
\hline S. aureus ATCC 6538 & 1.6 & 25.6 & 1.6 & 25.6 & 6.4 & 102.4 \\
\hline S. aureus $173^{\mathrm{a}}$ & 1.6 & 25.6 & 1.6 & 25.6 & 6.4 & 102.4 \\
\hline S. aureus $187^{\mathrm{a}}$ & 1.6 & 25.6 & 1.6 & 25.6 & 6.4 & 102.4 \\
\hline S. aureus $298^{\mathrm{a}}$ & 1.6 & 12.8 & 1.6 & 12.8 & 12.8 & 51.2 \\
\hline E. coli ATCC 11229 & 3.2 & 6.4 & 3.2 & 6.4 & 51.2 & 51.2 \\
\hline E. coli $475^{\mathrm{a}}$ & 3.2 & 6.4 & 3.2 & 6.4 & 51.2 & 51.2 \\
\hline E. coli $555^{\mathrm{a}}$ & 3.2 & 6.4 & 3.2 & 6.4 & 6.4 & 25.6 \\
\hline E. coli $574^{\mathrm{a}}$ & 3.2 & 3.2 & 3.2 & 6.4 & 12.8 & 25.6 \\
\hline K. pneumoniae ATCC 4352 & 3.2 & 3.2 & 6.4 & 6.4 & 6.4 & 12.8 \\
\hline K. pneumoniae $626^{\mathrm{a}}$ & 3.2 & 3.2 & 3.2 & 3.2 & 12.8 & 51.2 \\
\hline
\end{tabular}

${ }^{a}$ Clinical isolates

Table $4 \mathrm{MIC}$ and $\mathrm{MBC}$ values of crystalline $\mathrm{TiO}_{2 \mathrm{a}}: \mathrm{Ag}^{0}, \mathrm{TiO}_{2 \mathrm{a}}: \mathrm{Ag}^{0} / \mathrm{Ag}^{+}$and $\mathrm{TiO}_{2 \mathrm{a}}: \mathrm{Ag}^{0} / \mathrm{Ag}^{0}$ of references and clinical bacteria strains

\begin{tabular}{|c|c|c|c|c|c|c|}
\hline Bacteria strains & $\begin{array}{l}\mathrm{MIC}(\mu \mathrm{g} / \mathrm{ml}) \\
\mathrm{TiO}_{2 \mathrm{a}}: \mathrm{Ag}^{0}\end{array}$ & $\mathrm{MBC}(\mu \mathrm{g} / \mathrm{ml})$ & $\begin{array}{l}\mathrm{MIC}(\mu \mathrm{g} / \mathrm{ml}) \\
\mathrm{TiO}_{2 \mathrm{a}}: \mathrm{Ag}^{0} / \mathrm{Ag}^{+}\end{array}$ & $\mathrm{MBC}(\mu \mathrm{g} / \mathrm{ml})$ & $\begin{array}{l}\text { MIC }(\mu \mathrm{g} / \mathrm{ml}) \\
\mathrm{TiO}_{2 \mathrm{a}}: \mathrm{Ag}^{0} / \mathrm{Ag}^{0}\end{array}$ & $\operatorname{MBC}(\mu \mathrm{g} / \mathrm{ml})$ \\
\hline S. aureus ATCC 6538 & 0.4 & 0.4 & 1.6 & 3.2 & 0.8 & 12.8 \\
\hline S. aureus $173^{\mathrm{a}}$ & 0.4 & 0.4 & 1.6 & 3.2 & 0.8 & 12.8 \\
\hline S. aureus $187^{\mathrm{a}}$ & 0.4 & 0.4 & 1.6 & 3.2 & 3.2 & 12.8 \\
\hline S. aureus $298^{\mathrm{a}}$ & 0.4 & 0.4 & 1.6 & 3.2 & 0.8 & 12.8 \\
\hline E. coli ATCC 11229 & 0.4 & 0.8 & 3.2 & 3.2 & 1.6 & 12.8 \\
\hline E. coli $475^{\mathrm{a}}$ & 0.4 & 0.8 & 1.6 & 3.2 & 1.6 & 12.8 \\
\hline E. coli $555^{\mathrm{a}}$ & 0.4 & 0.4 & 1.6 & 1.6 & 0.4 & 6.4 \\
\hline E. coli $574^{\mathrm{a}}$ & 0.4 & 0.4 & 1.6 & 1.6 & 0.8 & 6.4 \\
\hline K. pneumoniae ATCC 4352 & 0.4 & 0.4 & 1.6 & 1.6 & 0.8 & 3.2 \\
\hline K. pneumoniae $626^{\mathrm{a}}$ & 0.4 & 0.8 & 1.6 & 3.2 & 0.8 & 3.2 \\
\hline
\end{tabular}

${ }^{a}$ Clinical isolates

Thiel et al. [8] suggested that efficient bactericidal behavior of silver nanoparticles results from the amounts of silver: the higher number of silver atoms on the surface, the higher the antibacterial effect. We indicated that the contents of silver have an influence on the antibacterial effect but is inversely proportional to bactericidal efficacy.

Received results indicate differences between microorganisms belonging to two groups. From our test data results that Gram-negative bacteria (tested E. coli and K. pneumoniae) are more sensitive to silver nanoforms than Grampositive $S$. aureus. This may result from a difference in the building of the cell-wall. Guillard et al. [7] propose that bacteria which have more fimbriae are more quickly inactivated in the presence of $\mathrm{TiO}_{2} / \mathrm{Ag}^{0}$ than those without fimbriae. These protein surface structures help adhere the bacteria cell to $\mathrm{TiO}_{2}$ carriers. It is well known that fimbriae are produced more by Gram-negative bacteria than Grampositive [34], so we suggest that the higher sensitivity of
E. coli and K. pneumoniae results from the presence of fimbriae on the surface of these bacteria.

\section{Conclusions}

Modified sol-gel technology has made it possible to synthesize nanoparticles of $\mathrm{TiO}_{2}$ with a diameter about $50 \mathrm{~nm}$. Preparation of silver-coated $\mathrm{TiO}_{2}$ is possible by the impregnation and chemical reduction of silver ions during the synthesis of $\mathrm{TiO}_{2}$. An amorphous $\mathrm{TiO}_{2}$ heated at $400^{\circ} \mathrm{C}$ transformed into crystalline anatase. The surface area of $\mathrm{TiO}_{2}$ decreases while pore size increases during calcination. Sensitivity of tested bacteria strains to silver impregnated $\mathrm{TiO}_{2}$ depends on the crystalline form of carrier, silver particle size, powder surface area, its porosity, the content of silver, and its oxidation state. We have proven that crystalline $\mathrm{TiO}_{2}$ may be very good carrier for 
silver. Samples synthesized by us may be used as very attractive antimicrobial agents excluding additional factor such as UV irradiation.

Acknowledgments This work was supported by grant Ministry of Science and Higher Education NO. NN405 193136. The authors thank dr Jerzy Kowalczyk for research support and dr Kamila Korzekwa for collection of bacteria strains.

Open Access This article is distributed under the terms of the Creative Commons Attribution License which permits any use, distribution, and reproduction in any medium, provided the original author(s) and the source are credited.

\section{References}

1. Frank S, Bard AJ (1977) Heterogenous photocatalytic oxidation of cyanide ion in aqueous solution at $\mathrm{TiO}_{2}$ powder. $\mathrm{J}$ Am Chem Soc 99:303-304

2. Frank SN, Bard AJ (1977) Heterogenous photocatalytic oxidation of cyanide and aqueous solutions at semiconductor powders. J Phys Chem 81:1484-1488

3. Fujishima A, Honda K (1972) Electrochemical photolysis of water at a semiconductor electrode. Nature 238:37-38

4. Fujishima A, Rao TN, Tryk DA (2000) Titanium dioxide photocatalysis. J Photochem Photobiol A Photochem Rev 1:1-21

5. Alrousan DMA, Dunlop PSM, McMurray TA, Byrne JA (2009) Photocatalytic inactivation of $E$. coli in surface water using immobilized nanoparticles $\mathrm{TiO}_{2}$ films. Water Res 43:47-54

6. Akhavan $\mathrm{O}$ (2009) Lasting antibacterial activities of $\mathrm{Ag}-\mathrm{TiO}_{2} /$ $\mathrm{Ag} / \mathrm{a}-\mathrm{TiO}_{2}$ nanocomposite thin film photocatalyst under solar light irradiation. J Colloid Interface Sci 336:117-124

7. Guillard Ch, Bui TH, Felix C, Moules V, Lina B, Lejeune P (2008) Microbiological disinfection of water and air by photocatalysis. C.R. Chimie 11:107-113

8. Thiel J, Pakstis L, Buzby S, Raffi M, Ni C, Pochan DJ (2007) Antibacterial properties of silver-doped titania. Small 5:799-803

9. Matsunaga T, Tamoda R, Nakajima T, Wake H (1985) Photoelectrochemical sterilization of microbial cells by semiconductor powders. FEMS Microbiol Lett 29:211

10. Dror-Ehre A, Mamane H, Belenkova T, Markovich G, Adin A (2009) Silver nanoparticles- $E$. coli colloidal interaction in water and effect on E. coli survival. J Colloid Interface Sci 339: 521-526

11. Molski M (2009) Chemia piękna. PWN, Warszawa

12. Li Y, White T, Lim SH (2003) Structural control and its influence on photoactivity and phase transformation of titania nanoparticles. Ann Rev Mater Sci 5:211-215

13. Yin HB, Wada Y, Kitamura T, Kambe S, Murasawa S, Mori $\mathrm{H}$ et al (2001) Hydrothermal synthesis of nanosized anatase and rutile $\mathrm{TiO}_{2}$ using amorphous phase $\mathrm{TiO}_{2}$. J Mat Chem 11:16941703

14. Bugla-Płoskońska G, Leszkiewicz A, Borak B, Jasiorski M, Drulis-Kawa Z, Baszczuk A et al (2007) Bactericidal properties of silica particles with silver islands located on the surface. Int $\mathbf{J}$ Antimicrob Agents 29:738-748

15. Jasiorski M, Leszkiewicz A, Brzeziński S, Bugla-Płoskońska G, Malinowska G, Borak B (2009) Textile with silver silica spheres: its antimicrobial activity against $E$. coli and $S$. aureus. J Sol-Gel Sci Tech 51:330-334
16. Bugla-Płoskońska G, Jasiorski M, Leszkiewicz A, Borak B, Drulis-Kawa Z, Baszczuk A (2008) Silver nanoislands located on the silica spheres and its antimicrobial activity against $K$. pneumoniae strain. Nano Sci Nano Tech Indian J 2(2-3):45-47

17. Bugla-Płoskońska G, Jasiorski M, Leszkiewicz A, Borak B, Baszczuk A, Brzeziński S et al (2008) Bakteriobójcze działanie immobilizowanych preparatów srebra i możliwość ich praktycznego zastosowania. Farm Przegl Nauk 37:23-26

18. Samuel U, Guggenbichler JP (2004) Prevention of catheterrelated infections: the potential of a new nano-silver impregnated catheter. Int J Antimicrob Agents 23S1:75-78

19. Kojło A, Godlewska-Żyłkiewicz B (2007) Wykorzystanie mikroorganizmów do wydzielania śladów metali w przepływowych technikach analitycznych. Laboratorium-Przegląd Ogólnopolski 6:24-28

20. Atiyeh BS, Costagliola M, Hayek SN, Dibo SA (2007) Effect of silver on burn wound infection control and healing: review of the literature. Burns 33:139-148

21. Silver S (2003) Bacterial silver resistance: molecular biology and uses and misuses of silver compounds. Microbiology 27:341-353

22. Rosen BP (1996) Bacterial resistance to heavy metals and metalloids. J Biol Inorg Chem 1:273-277

23. Stöber W, Fink A, Bohn E (1968) Controlled growth of monodisperse silica spheres in micro size range. J Colloid Interface Sci 26:62-69

24. Peterson MSM, Bouwman J, Chen A, Deutsch M (2007) Inorganic metallodielectric materials fabricated using two single step methods based on the Tollen's process. J Colloid Interface Sci 306:41-49

25. Wysocka K, Leszkiewicz A, Kowalczyk J, Stręk W, Doroszkiewicz W, Podbielska H (2007) Nanomateriały krzemionkowe domieszkowane srebrem i ich możliwe zastosowania $\mathrm{w}$ medycynie. Acta Bio-Opt Inf Med 3(13):22-25

26. National Committee for Clinical Laboratory Standards (2000) Methods for dilution antimicrobial susceptibility tests for bacteria that grow aerobically. Approved standard-fifth edition M7-A5, 20(2)

27. Hryniewicz W, Sulikowska A, Szczypa K, Skoczyńska A, Łuczak-Kadłubowska A, Gniatkowski M (2006) Rekomendacje doboru testów do oznaczania wrażliwości bakterii na antybiotyki i chemioterapeutyki. Polish National Institute of Public Heath, Warszawa

28. Wetchakun N, Phanichphant S (2008) Effect of temperature on the degree of anatase-rutile transformation in titanium dioxide nanoparticles by the modified sol-gel method. Curr App Phys 8:343-346

29. Chao HE, Yun YU, Xingfang HU, Larbot A (2003) Effect of silver doping on the phase transformation and grain growth of sol-gel titania powder. J Eur Ceram Soc 23:1457-1464

30. Seery MK, George R, Floris P, Pillai SC (2007) Silver doped titanium dioxide nanomaterials for enhanced visible light photocatalysis. J Photochem Photobiol A Chem 189:258-263

31. Li H, Duan X, Liu G, Liu X (2008) Photochemical synthesis and characterization o $\mathrm{Ag} / \mathrm{TiO}_{2}$ nanotube composites. J Mater Sci 43:1669-1676

32. Mohammadi MR, Fray DJ, Mohammadi A (2008) Sol-gel nanostructured titanium dioxide: controlling the crystal structure, crystallite size, phase transformation, packing and ordering. Micro Meso Mater 112:392-402

33. Keleher J, Bashant J, Heldt N, Johnson L, Li Y (2002) Photocatalytic preparation of silver-coated $\mathrm{TiO}_{2}$ particles for antibacterial applications. World J Microbiol Biotechnol 18:133-139

34. Baj J, Markiewicz Z (2006) Biologia molekularna bakterii. PWN, Warszawa 